\title{
Plankton community as an indicator of water quality in tropical shrimp culture ponds
}

\author{
Maristela Casé ${ }^{\mathrm{a}}$, Enide Eskinazi Leça ${ }^{\mathrm{b}}$, Sigrid Neumann Leitão ${ }^{\mathrm{c}, *}$, \\ Eneida Eskinazi Sant'Anna ${ }^{\mathrm{d}}$, Ralf Schwamborn ${ }^{\mathrm{e}, \mathrm{f}}$, Antônio Travassos de Moraes Junior ${ }^{\mathrm{b}}$

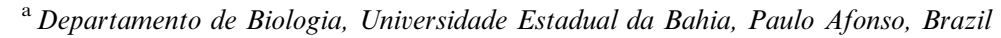 \\ ${ }^{\mathrm{b}}$ Departamento de Biologia, Universidade Federal Rural de Pernambuco, Recife, Brazil \\ ${ }^{\mathrm{c}}$ Departamento de Oceanografia, Universidade Federal de Pernambuco, Av. Arquitetura s/n, Cidade Universitária, 50.730-540 Recife, Pernambuco, Brazil \\ ${ }^{\mathrm{d}}$ Departamento de Oceanografia e Limnologia, Universidade Federal do Rio Grande do Norte, Natal-Rio Grande do Norte, Brazil \\ ${ }^{\mathrm{e}}$ Department of Animal Ecology, Alfred Wegener Institute for Polar and Marine Research (AWI), Am Alten Hafen 26, D-27568, Bremerhaven, Germany \\ ${ }^{\mathrm{f}}$ Departamento de Zoologia, Universidade Federal de Pernambuco, Recife, Pernambuco, Brazil
}

\begin{abstract}
The plankton was examined as an indicator of water quality in 14 shrimp Litopenaeus vannamei farms in Brazil in 2003 . The ponds were categorized by high stocking density $\left(>30 \mathrm{PL} \mathrm{m}^{-2}\right)$ of phytoplankton, consisting of 51 species with concentrations ranging from $365,218 \pm 416,615$ cells $\mathrm{mL}^{-1}$ to $1,961,675 \pm 3,160,172$ cells $\mathrm{mL}^{-1}$. Diatoms contributed to almost $70 \%$ of the species number and high densities resulted from Cyanophyta blooms, mainly Pseudanabaena cf limnetica. Forty zooplankton taxa were registered and were essentially composed of typical marine euryhaline species and suspension-feeders. Copepoda dominated (45\%) the make-up, followed by Protozoa $(18 \%)$, Rotifera (12\%), and Mollusca (12\%) larvae. Zooplankton varied from $972 \pm 209 \mathrm{ind}^{-3}$ to $4235 \pm 2877$ ind $\mathrm{m}^{-3}$. Enhanced nutrient input affected plankton density and composition. Diatom and Copepoda dominance was replaced by cyanobacteria, protozoan, and rotifers as nutrient concentrations increased with the cultured period, indicating that plankton structure is affected by eutrophic conditions.
\end{abstract}

(c) 2008 Elsevier Ltd. All rights reserved.

Keywords: Phytoplankton; Zooplankton; Aquaculture; Shrimp ponds; Litopenaeus vannamei; Brazil

\section{Introduction}

The expectation for aquaculture to increase its contribution to global food supplies and the sustained global demand for shrimp, which cannot be met by fisheries alone, provides an economic incentive for intensive shrimp farming (Burford et al., 2003). However, shrimp culture requires water, land, and other natural resources, which inevitably interact with the environment. The expansion of shrimp farming in many coastal regions is the leading cause of the loss of mangrove forests. Furthermore, other forms of coastal deterio-

\footnotetext{
* Corresponding author. Tel.: +55812126 7220; fax: +55 8121268227. E-mail address: sigrid@terra.com.br (S.N. Leitão).
}

ration by shrimp farms (eutrophication, use of antibiotics, introduction of exotic species etc.) have lead to wide-spread criticism (Naylor et al., 1998; Alongi et al., 1999) and global efforts to develop sustainable shrimp production management practices (Samocha et al., 2004).

Mariculture is a recent development of the Brazilian agribusiness, and has increased by about $20 \%$ per year during the last decade, particularly along the semi-arid north eastern coast of Brazil, due to the good weather conditions and environmental setting (Lacerda et al., 2006).

Cultured shrimp has been the driving force behind the strong increase in shrimp trade during the late 1980s and early 1990s, making its value the most important seafood product traded internationally. In fact, over one quarter of the shrimp traded internationally comes from aquaculture 
(FAO, 1998). This rapid development has been accompanied by increasingly controversial debates over the environmental, social, and economic impacts of shrimp culture (PaezOsuna et al., 1998, 1999; Primavera, 1998; Costanzo et al., 2004; Sampaio et al., 2005). There is considerable uncertainty about appropriate policy and management responses, especially as shrimp culture is perceived to generate substantial benefits in coastal regions and at the national level (Rocha et al., 2004).

The rapid expansion of shrimp farming in Brazil has focused attention on the need for effective management strategies. Such strategies are needed to enhance the positive contributions that shrimp farming and other forms of coastal aquaculture can make to economic growth and poverty alleviation in coastal areas, while controlling negative environmental and social impacts that may accompany poorly planned and regulated developments (Rocha et al., 2004).

The water quality associated with aquaculture developments is an important concern globally, as a variety of negative environmental impacts on the receiving environment have been documented (Landesman, 1994; Lacerda et al., 2006). Most importantly, it is the water quality that will influence optimal shrimp growth and yield. Classically, an investigation of water quality involves a combination of physical variables and biological indicators (Jones et al., 2001). The fact that intensive mariculture often involves the addition of various feeds, fertilizers, and chemicals to stabilize the earthen pond bottoms, the use of only classic physicochemical variables to accurately assess the water quality in and around these systems may be inadequate.

Additionally, there is still insufficient information on the use of the plankton communities as biological indicators of water quality associated with culture systems, especially in marine environments.

Phytoplankton and zooplankton make excellent indicators of environmental conditions and aquatic health within ponds because they are sensitive to changes in water quality. They respond to low dissolved oxygen levels, high nutrient levels, toxic contaminants, poor food quality or abundance, and predation. A good picture of the current conditions in the ponds can be derived by looking at plank- ton indicators, such as their biomass, abundance, and species diversity (Burford, 1997; Primavera, 1998).

Because it is desirable that ponds and other waters should support phytoplankton and zooplankton species for maintaining good water quality as well as providing a quality food source for the others consumers, it is important to elucidate the trends of species dominance and the probable factors controlling the community structure. Therefore, the objective of this study is to provide information on the usefulness of phytoplankton and zooplankton species as indicators of water quality in shrimp aquaculture.

\section{Materials and methods}

This research was based in 108 phytoplankton and 108 zooplankton samples collected during three sessions $(\mathrm{C} 1$, C2 and C3) from October 10th to November 19th 2003 from 14 farms that intensively cultivate the marine shrimp Litopenaeus vannamei. C1 was carried out from 19th to 25th October, C2 from 1st to 7th November, and C3 from 14th to 17th November. On each farm, two ponds (P1 and P2) and the water intake point (IP) were monitored. The farms are located in Ceará, Piauí and Rio Grande do Norte states - Brazil (Table 1, Fig. 1) and produce shrimp by intensive culture (30-80 shrimps $\mathrm{m}^{-2}$ ), in ponds, typically 1 ha each in size with earthen floors, feeding exclusively with a balanced commercial ration. The mean survival rate varied from 42.53 to $55.12 \%$, the days of cultivation from 132 to 159 days, and the final weight from 10.66 to $12.54 \mathrm{~g}$.

Water samples for phytoplankton were collected with a $100 \mathrm{~mL}$ plastic bottle, and samples were preserved with $1 \%$ Lugol's iodine solution. Quali-quantitative analyses were carried out in the laboratory using the Ütermol method under an inverted microscope. The phytoplankton composition was based on the identification of the specific and infra-specific taxa.

Zooplankton sampling at each station was collected with a standard plankton net of $1 \mathrm{~m}$ length, $30 \mathrm{~cm}$ mouth diameter, and mesh size of $50 \mu \mathrm{m}$ fitted with a flowmeter (Hydrobios, Kiel). Three minutes of horizontal sub-surface hauls were made at each pond. Samples were preserved in a

Table 1

Shrimp culture farms in Northeastern Brazil

\begin{tabular}{|c|c|c|c|c|c|}
\hline FARMS (City) & Latitude & Longitude & $\begin{array}{l}\text { Survival }(\%) \\
\min -\max ^{\mathrm{a}}\end{array}$ & $\begin{array}{l}\text { Days of cultivation } \\
\text { min-max }\end{array}$ & $\begin{array}{l}\text { Final Weight }(\mathrm{g}) \\
\min -\max \end{array}$ \\
\hline \multicolumn{6}{|l|}{ Ceará State } \\
\hline Promares, Aquafort and Samarisco (Camocim) & $2^{\circ} 54^{\prime} \mathrm{S}$ & $40^{\circ} 50^{\prime} \mathrm{W}$ & $40.46-70.11$ & $102-158$ & $9.73-14.28$ \\
\hline Papagaio and AS Marine (Acaraú) & $2^{\circ} 50^{\prime} \mathrm{S}$ & $40^{\circ} 07^{\prime} \mathrm{W}$ & $43.62-52.90$ & $120-172$ & $10.23-11.11$ \\
\hline Compescal, Cina and Vip Camarões (Aracati) & $4^{\circ} 33^{\prime} \mathrm{S}$ & $37^{\circ} 46^{\prime} \mathrm{W}$ & $32.58-52.78$ & $116-142$ & $10.28-11.23$ \\
\hline \multicolumn{6}{|l|}{ Piaui State } \\
\hline Camapi, Secom and Camarões do Brasil (Cajueiro da Praia) & $2^{\circ} 55^{\prime} \mathrm{S}$ & $41^{\circ} 20^{\prime} \mathrm{W}$ & $52.51-64.10$ & $128-160$ & $10.24-11.04$ \\
\hline $\begin{array}{l}\text { Rio Grande do Norte State } \\
\text { Potiporã }^{*}, \mathrm{MRG}^{*} \text { and Aquática* (Pendências) }\end{array}$ & $06^{\circ} 16^{\prime} \mathrm{S}$ & $35^{\circ} 29^{\prime} \mathrm{W}$ & $37.57-66.27$ & $142-174$ & $11.03-13.21$ \\
\hline
\end{tabular}

\footnotetext{
* Samples collected during the 2nd and 3rd campaigns.

${ }^{\text {a }}$ Min-max $=$ Minimum and maximum Data information: http://www.abccam.com.br/.
} 


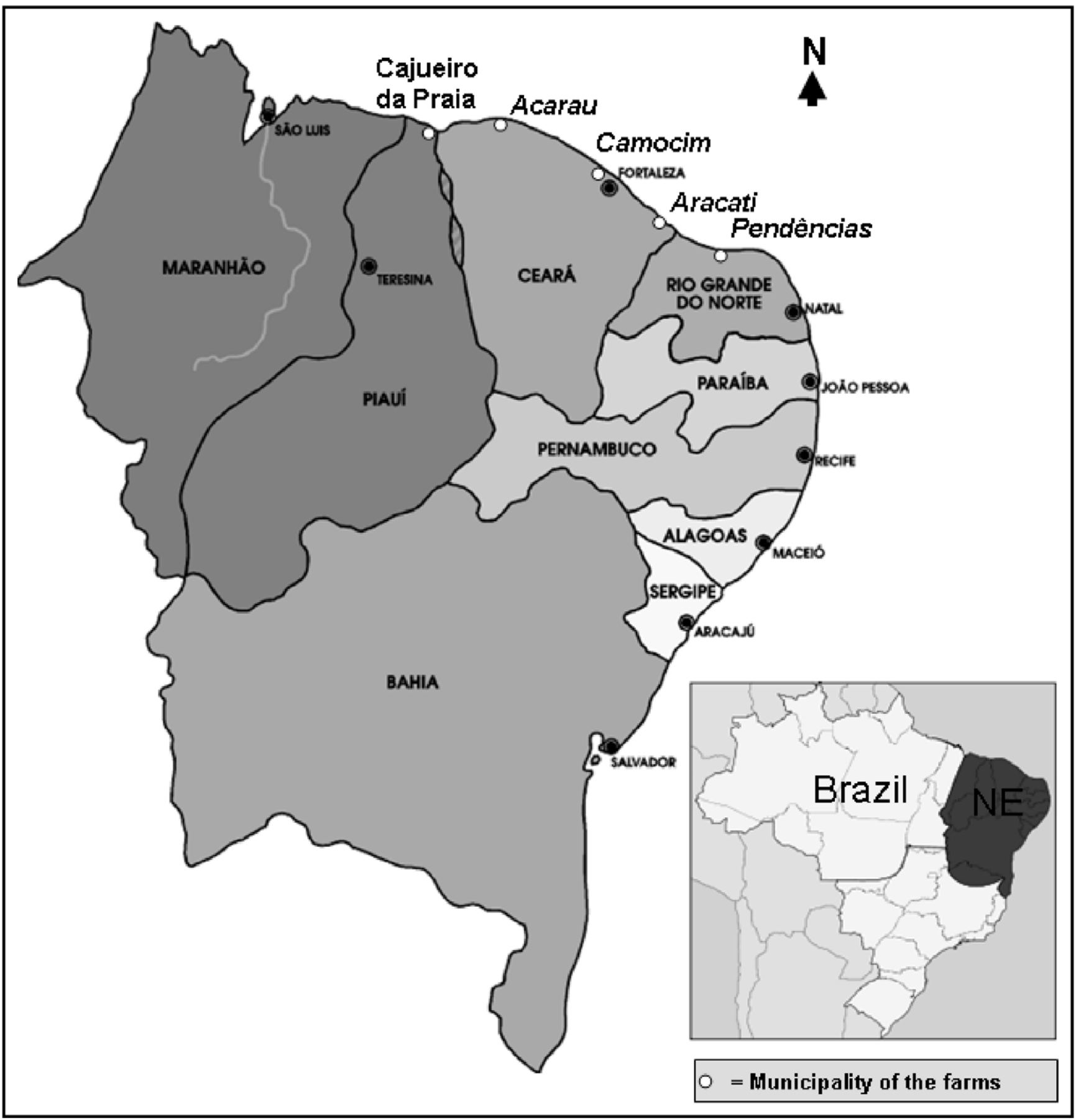

Fig. 1. Studied area in Northeastern Brazil showing the municipalities where the farms are located.

$4 \%$ buffered formalin/seawater solution. Zooplankton species were identified to the lowest taxonomic unit possible, and taxon abundance (per cubic meter) was counted under a microscope ( $1 \mathrm{~mL}$ sub sample). These samples were taken with a Stempel-pipette from the entire sample $(250 \mathrm{~mL})$.

The Shannon index $\left(H^{\prime}\right)$ was applied for the estimation of phytoplankton and zooplankton community diversity based on $\log _{2}$ (Shannon, 1948). Evenness was calculated according to Pielou (1967).
To verify potential correlations between farms, Spearman rank correlation analysis (Zar, 1990) was performed at $\alpha=0.05$. One-way Kruskall-Wallis ANOVA (Zar, $1990)$ was used to test for significant $(\alpha=0.05)$ effects of the factors "station", "campaign", and "farm" on the phyto- and zooplankton data from all farms. No effect of the factor "State" was tested as Ceará State had eight of the 14 farms. These analyses were performed with STATISTICA 5.1 (StatSoft Inc.). 


\section{Results and discussion}

\subsection{Phytoplankton}

The exclusive use of physicochemical indicators to assess the water quality of intensive mariculture system is insufficient, particularly if there is an investigation into the extent of the influence of the farm wastewater on the immediate environs. This observation concurs with previous studies concluding that the use of traditional water quality indices to determine the effect of aquaculture effluent on the receiving environment is mainly limited to areas near to the discharge point (Samocha and Lawrence, 1995).

The use of phytoplankton biomass as an indicator for this type of system is sufficient, but it has specific limitations. Firstly, the total chlorophyll $a$ values may be underestimated in areas having high macroalgal populations. The absorption of nutrients by the macroalgae may result in an underestimated biomass value and, consequently, an inaccurate characterization of the water quality. The size fractions of the phytoplankton are important on a microscopic level in the determination of water quality. However, the presence of colonial phytoplankton species may overestimate the contribution of a size class to the total biomass at that site. Thus, it is important to know the species composition, as phytoplankton undergoes a continual succession of dominant species due to dynamic changes of growth factors like light, temperature, and nutrient concentrations in an aquatic environment (Goldman and Mann, 1980; Yusoff and McNabb, 1997; Yusoff et al., 2002).

In the studied shrimp ponds, a total of 51 species were identified, with diatoms contributing to $69 \%$ of the species list followed by Pyrrophyta (8\%), Cyanophyta (12\%), Euglenophyta (4\%), and Chlorophyta $(6 \%)$. This confirms the high diversity of diatoms in estuarine waters. The less representative algae were Euglenoficeans and Criptoficeans that were represented by only one species each. Phytoplankton does not only affect water quality, but also the other organisms along the food chain. Centric diatoms have been classified as the most desirable phytoplankton in coastal waters (Ryther and Officer, 1981) because they are important as food items for higher consumers (Boyd, 1990). However, some marine diatoms negatively affect the reproduction of dominant zooplankton grazers such as copepods, thus compromising the transfer of energy through marine food chains. For example, some centric species (Chaetoceros convolutus and C. concavicornis) can form noxious blooms that have been implicated in fish kills for at least 30 years, the causative mechanism being unknown (Horner et al., 1991). Some diatoms are producers of toxins or grazing deterrents (D'Ippolito et al., 2003; Romano et al., 2003; Fontana et al., 2007).

In areas where temperature is high and light is abundant (like in Northeastern Brazil), nutrient concentrations and ratios become important environmental factors influencing the dominance of various taxonomic groups (Smith, 1983;
Yusoff and McNabb, 1997). In general, algae from diverse groups have remarkably similar physiological and compositional response to nutrient limitation. Thus, such responses are useful indicators of nutrient status (Healy, 1973).

The most frequent phytoplankton species in the studied ponds were Pseudoanabaena limnetica cf., Scrippsiella trochoidea, Gymnodinium sp., Cyclotella meneghiniana, and Chlorella sp. Smith (1983) reported that nutrient-loading ratios can exert a strong selective effect on natural communities of phytoplankton. In shallow ecosystems like ponds, high availability of phosphorus and nitrogen in interstitial water can be an additional source of nutrients for phytoplankton blooms. Also, approximately $80 \%$ of the nitrogen added to ponds as shrimp feed is not retained in shrimp biomass, instead acting as a phytoplankton fuel (Sanders et al., 1987).

The dominance of the above phytoplankton species in most studied farms led to very low phytoplankton species diversity, with an average value on all farms of $0.76 \pm 0.25$ bits cell $^{-1}$, varying from 0.5 to 1.1 bits cell $^{-1}$ (Fig. 2). The highly unbalanced system favored irregular blooms of some species, showing that the ponds present low species number and low evenness. According to Paerl (1988), blooms exist as massive accumulations of a single or less often two coexisting species with densities of $10^{4}$ $10^{6}$ cells $\mathrm{mL}^{-1}$, and the nuisance species account for as much as $95-99 \%$ of the resident biomass. Smith (1985) suggested that highly diverse algal communities are less likely to collapse than blooms dominated by one species.

Phytoplankton density varied from 365,218 cells $\mathrm{mL}^{-1}$ (Farm Cina) to 1,961,675 cells $\mathrm{mL}^{-1}$ (Farm Camarões do Brasil) (Fig. 3). High densities resulted from some species blooms in most studied ponds. Cyanophyta were in general responsible for these blooms, especially Pseudanabaena of limnetica that attained values over 600,000 cells $\mathrm{mL}^{-1}$, as in the farms Papagaio (pond 2), Compescal (pond 2), and Vip Camarões (pond 2), which showed stressed conditions. Other farms displaying this species with densities over 200,000 cells $\mathrm{mL}^{-1}$ (A. S. Marine, pond 1; Riograndense, pond 1 and 2; Aquafort, pond 2; Samarisco, pond 2) need to be constantly monitored.

Nutrient levels of the water and interstitial water of the sediments has usually been used to characterize the water trophic state. We suggest that phytoplankton composition and density could also be used as a complementary indicator of water trophy degree.

Pseudanabaena cf. limnetica presented high densities in some farms' intake water channel, where the densities were over 100 cells $\mathrm{mL}^{-1}$. Papagaio, Vip Camarões and Rio Grandense farms were in this condition.

Another algae group with high densities was Chlorophyta, which presented very low species diversity. However, blooms of Chlorella sp. sometimes dominated the ponds. Blooms were registered in the farms Aquafort (pond 2), A. S. Marine (ponds 1 and 2), and Camapi (pond 1), where this species attained $1,000,000$ cells $\mathrm{mL}^{-1}$. Others farms must be monitored, as high densities were also registered 


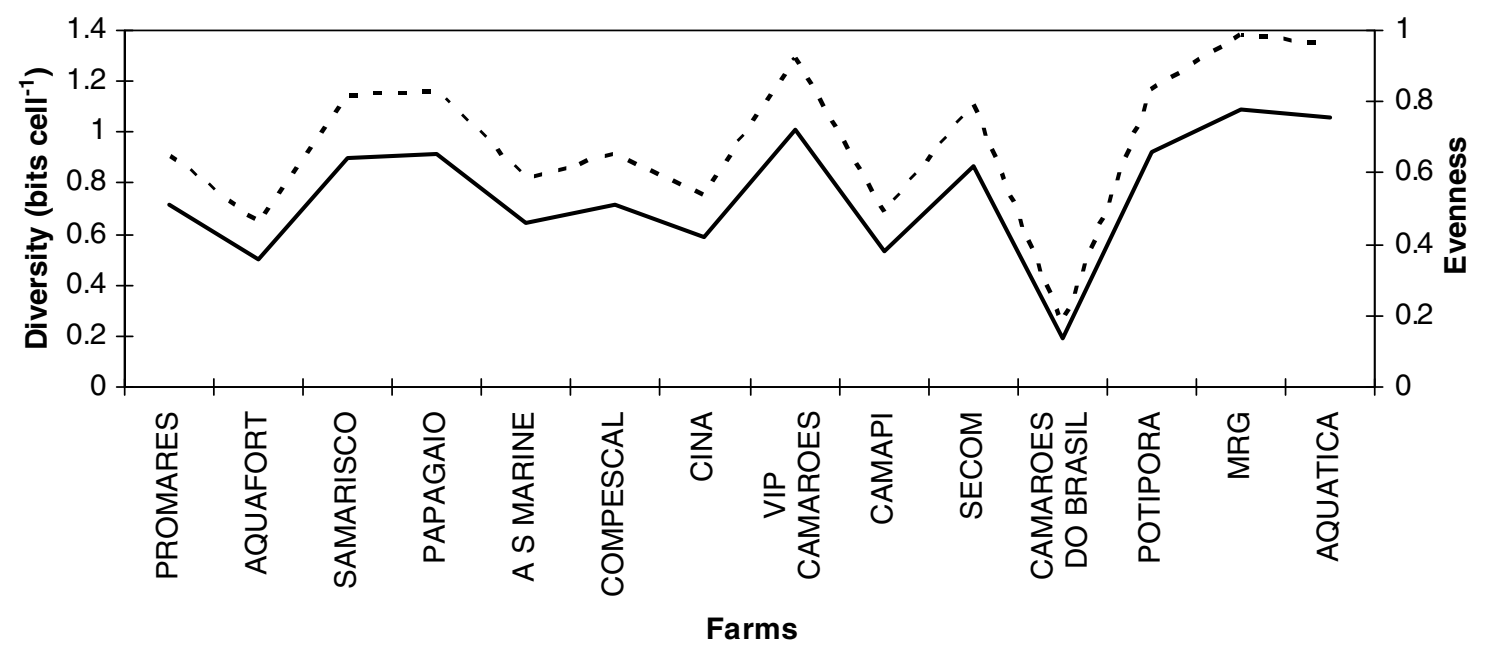

DIVERSITY - - - EVENNESS

Fig. 2. Species diversity and evenness of the main phytoplankton groups in the shrimp farm ponds in Northeastern Brazil.

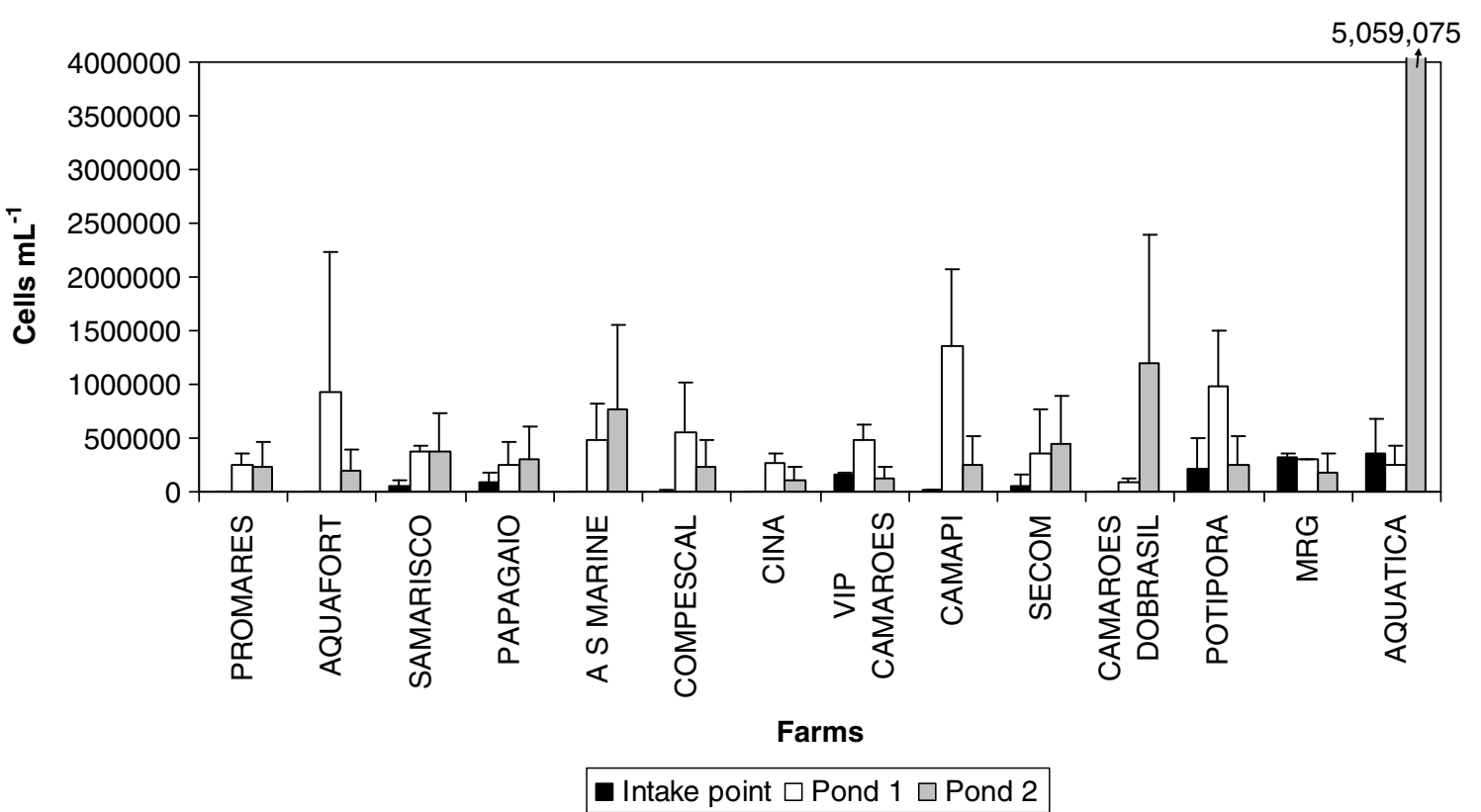

Fig. 3. Total phytoplankton average density and standard deviation in the shrimp farm ponds in Northeastern Brazil.

(over 200,000 cells $\mathrm{mL}^{-1}$ ) in the farms Promares (pond 1), Samarisco (pond 1), Compescal (pond 1), and Vip Camarões (pond 1).

Studies carried out on phytoplankton on shrimp farms in Bangladesh by Islam et al. (2004) identified phytoplankton only to genera. Bacillariophyceae was the largest group by quality, being represented by up to 13 genera, while Pyrrophyceae was the smallest group, represented by only two genera. Bacillariophyceae numbers dominated two ponds, and Cyanophyceae dominated the other ponds. Phytoplankton density attained 211 cells $\mathrm{mL}^{-1}$. The phytoplankton groups in the present study were almost the same as the assemblage found by Tookwinas and Songsangjinda (1999), who reported 79 genera in ponds of the shrimp farming system in Thailand, with concentrations ranging from 1822 to 72,527 cells $\mathrm{mL}^{-1}$.

In shrimp ponds from Mexico, Rodriguez and Paez-Osuna (2003) listed 48 genera of phytoplankton that commonly occur in coastal areas. They also reported Bacillariophyceae, Cyanophyceae, Chlorophyceae, and Euglenophyceae as the dominant groups in coastal waters and in the shrimp farming systems. Among the most common pond types (intensive and semi-intensive), Synechocystis diplococcus (cyanobacteria) was the dominant species $(>88.9 \%)$, followed by 
Peridinium trochoideum (Scrippsiella trochoidea), and eventually by Prorocentrum minimum and Gymnodinium spp. (dinoflagellates). The numerous occurrences of large blooms of dinoflagellates and other functional groups such as cyanobacteria, diatoms, chlorophytes, and flagellates mean economic losses for the farm industry on account of shrimp mortality or growth diminution due to poisoning, anoxic, or mucus production effects.

In the pristine marine tropical waters in Brazil, diatoms normally comprise more than $80 \%$ of the total phytoplankton (Eskinazi-Leça et al., 2000). As in other coastal regions of the world, with the onset of eutrophication, diatom population decrease and other groups of algae, such as dinoflagellates and cyanobacteria, persist (Sanders et al., 1987; Yusoff et al., 2002). This could be caused by silica depletion, as domestic waste waters are relatively poor in silica, leading to elimination of diatoms from the phytoplankton communities (Ryther and Officer, 1981).

Phytoplankton blooms involving excessive algal growth are common occurrences in aquaculture ponds, which often lead to die-offs, decrease of water transparency, absence of oxygen in the bottom layer, and accumulation of toxic compounds such as ammonia, nitrite, and hydrogen sulphide (Paerl and Tucker, 1995). Due to the rapid onset of nutrient limitation (mainly nitrogen) or infestation by microorganisms (saprophytic fungi, bacteria, or protozoans), surface blooms are rapidly transformed into undesirable decomposing mats (Paerl, 1997).

In general, this study showed that in marine shrimp culture ponds, diatom dominance was potentially replaced by cyanobacteria as nutrient concentrations increased and silica was depleted with the culture period. However, this dominance could also be more closely associated with low aquatic luminosity than nutrient enhancement (Scheffer et al., 1997). Data obtained from some lakes associated with mathematical models indicate that cyanobacteria dominance is an alternative stable-state of a phytoplankton community in shallow aquatic systems. This is because cyanobacterians are more adapted to low water transparence, and they promote the water turbidity, favoring their own competitive advantages (Scheffer et al., 1997). Moreover, the long water retention time and abiogenic turbidity increase the probability of cyanobacteria dominance in shallow, tropical aquatic systems (Scheffer et al., 1997). Therefore, the high temperature and turbidity of the water and the long water retention time in shrimp ponds $(>100$ days) must raise the probability of cyanobacteria blooms.

The tendency of low species diversity is indicative of an unbalanced system with decreasing water quality and cultured species. Better conditions were found in the intake channels. The identification of phytoplankton composition in shrimp ponds is very important in terms of system management. For that reason, the management of water quality as well as the cultured organisms in shrimp farms is a complex task, which can benefit from a previous knowledge of taxonomic structure and quantitative patterns of phytoplankton assemblages.

\subsection{Zooplankton}

Zooplankton indices are also very useful water quality indicators for the shrimp culture farms. They displayed fairly distinct patterns in the species composition and abundance as the water quality changed spatially. This may be attributed to the fact that the zooplankton community itself responds directly or indirectly to changes in the physicochemical variables and the availability of phytoplankton food (Raymont, 1980), and is therefore less affected by manipulation via farm management processes. There have been numerous studies investigating the general zooplankton response to various sources of stress, and subsequently, their use as a biological indicator has been well documented (Webber and Webber, 1998). Zooplankton assemblages comprise a significant component of the natural biota of shrimp aquaculture ponds and present rapid temporal changes in structure (Coman et al., 2003; Preston et al., 2003).

The zooplankton was essentially composed of typical marine euryhaline species, which were distributed in 40 taxa. The following Phyla were present: Sarcomastigophora, Cnidaria, Nematoda, Rotifera, Mollusca, Annelida, Crustacea, Bryozoa, and Chordata. The dominant taxa were Copepoda (16 species and made up $44 \%$ of relative abundance), mainly as the juvenile form (nauplii and copepodits), followed by Protozoa (18\%), and Rotatoria (6 species with $12 \%$ of total relative abundance). The meroplankton was represented by Gastropoda and Bivalvia larvae $(12 \%)$, Polychaeta larvae with $7 \%$ of relative abundance (dominated by small chaetosphaera spionids), nauplii of Cirripedia, and few Brachyura zoeae stage I, with a large distribution in the Northeastern Brazil region sometimes dominating the community.

Among Copepoda, predominately, the Brazilian eurihaline-estuarine indicators were formed by the young stage of Parvocalanus crassirostris, Acartia lilljeborgi, Oithona oswaldocruzi, Oithona hebes, and Euterpina acutifrons (Björnberg, 1981; Neumann-Leitão et al., 1999).

The Protozoa, which outranked the atecate ciliata and tintinnina Tintinnopsis spp. and Favella ehrenbergi as being characteristic of the euthrophic systems, were indicators of unbalanced conditions. Tintinnids constitute an important component of the planktonic microprotozoan community in most marine environments (Pierce and Turner, 1993; Tillmann, 2004), and can occasionally be important in estuarine waters (Urrutxurtu, 2004). High abundance, fast reproduction rates, and short generation times, as well as their high capacity to use a large spectrum of food resources enhance the importance of tintinnids as a key trophic link between the microbial and the metazoan compartments (Capriulo and Carpenter, 1983; Capriulo et al., 2002; Urrutxurtu, 2004). In the recent past, researchers drew attention to the presence of large numbers of ciliates in intensive shrimp production systems, at least during part of the production cycle (Bratvold et al., 1999). However, their occurrence and role in the shrimp production systems 
have seldom been investigated. Decamp et al. (2007), studying shrimp culture ponds, found that free-swimming ciliates were dominant in the early stages of production and showed that ciliates could reach very high concentrations, over 6000 cells $\mathrm{mL}^{-1}$, within zero-water exchange shrimp production systems. However, none were identified.

Copepods, other crustaceans, larvae of polychaetes, larvae of insects, mollusks, ostracods, and rotifers have been considered the most important sources of food for shrimp (Rubright et al., 1981). The assemblages found in the studied ponds have a variety of roles within the pond ecosystem. Grazing zooplankton influences the dynamics of pond phytoplankton (Coman et al., 2003). Predation on zooplankton by shrimp (Martinez-Cordova et al., 1998) may transfer a significant proportion of the nutrients from natural biota to the shrimp tissue (Anderson et al., 1987), feces, and water. This, together with the nutrient input through shrimp rations, leads to the typically nutrient rich environment in shrimp ponds.

Rotifer Brachionus plicatilis was abundant in the aquaculture ponds. Rotifers are a valuable live food for larval fish and crustacean culture and have also been used as indicators of trophy (Saksena, 1987). Several characteristics of rotifers, including their nutritional quality, body size, and relatively slow motility, have contributed to their usefulness as good prey for active larvae (Snell and Carrillo, 1984). The rotifer Brachionus plicatilis has been most widely used as an essential food source in raising marine fish, shrimp, and crab larvae due to its tolerance to the marine environment (Lubzens, 1987). The rotifer B. plicatilis is a euryhaline species, and in nature, density peaks of these species are associated with high eutrophication near villages and/ or processing plants of aquatic and/or poultry products (Fenggi, 1996). B. plicatilis and others rotifer species dominated the estuarine region of the Ipojuca river (Northeastern Brazil), which receives high sewage loads from many cities and industries (Neumann-Leitão et al., 1992). Thus, the presence of these rotifers in high densities is indicative of the shrimp ponds nutrient enrichment and quality decrease.

Many stages of Nematoda, found at Cina and Papagaio farms, belonged to Ancylostoma duodenale. According to Rey (2002), the larvae develop in the aquatic environment during the rainy season between temperatures between 23 and $30{ }^{\circ} \mathrm{C}$, and the adults develop well in humid soil, rich in organic residuals.

In general, species diversity was low, following the same pattern as the phytoplankton. The lowest diversity index was found in Aquafort farm (1.26 bits ind $\left.{ }^{-1}\right)$ and the highest at Promares farm (1.75 bits ind $^{-1}$ ) (Fig. 4), due to few species, a common fact in estuarine waters (Tundisi, 1970) and in eutrophication conditions like in the ponds. Minimum evenness was registered at the Aquafort farm (0.44), caused by the dominance of few species (mainly atecate ciliata and Copepoda nauplii). The maximum was 0.6 (Fig. 4) at Vip Camarões farm, where the ecosystem presented better water quality, although still a somewhat poor condition.

Zooplankton total density by farm was high, with a minimum of 2915 ind $\mathrm{m}^{-3}$ (Vip camarões farm) and a maximum of 12,706 ind $\mathrm{m}^{-3}$ (Compescal farm). The average zooplankton abundance by site varied from $221.77 \pm 152.12$ ind $\mathrm{m}^{-3}$ (Cina farm, Pond 1) to $2513.35 \pm 1603.56$ ind $\mathrm{m}^{-3}$ (Compescal farm, Pond 1) (Fig. 5), with an average of all farms and sites of $2255 \pm 975$ ind $\mathrm{m}^{-3}$.

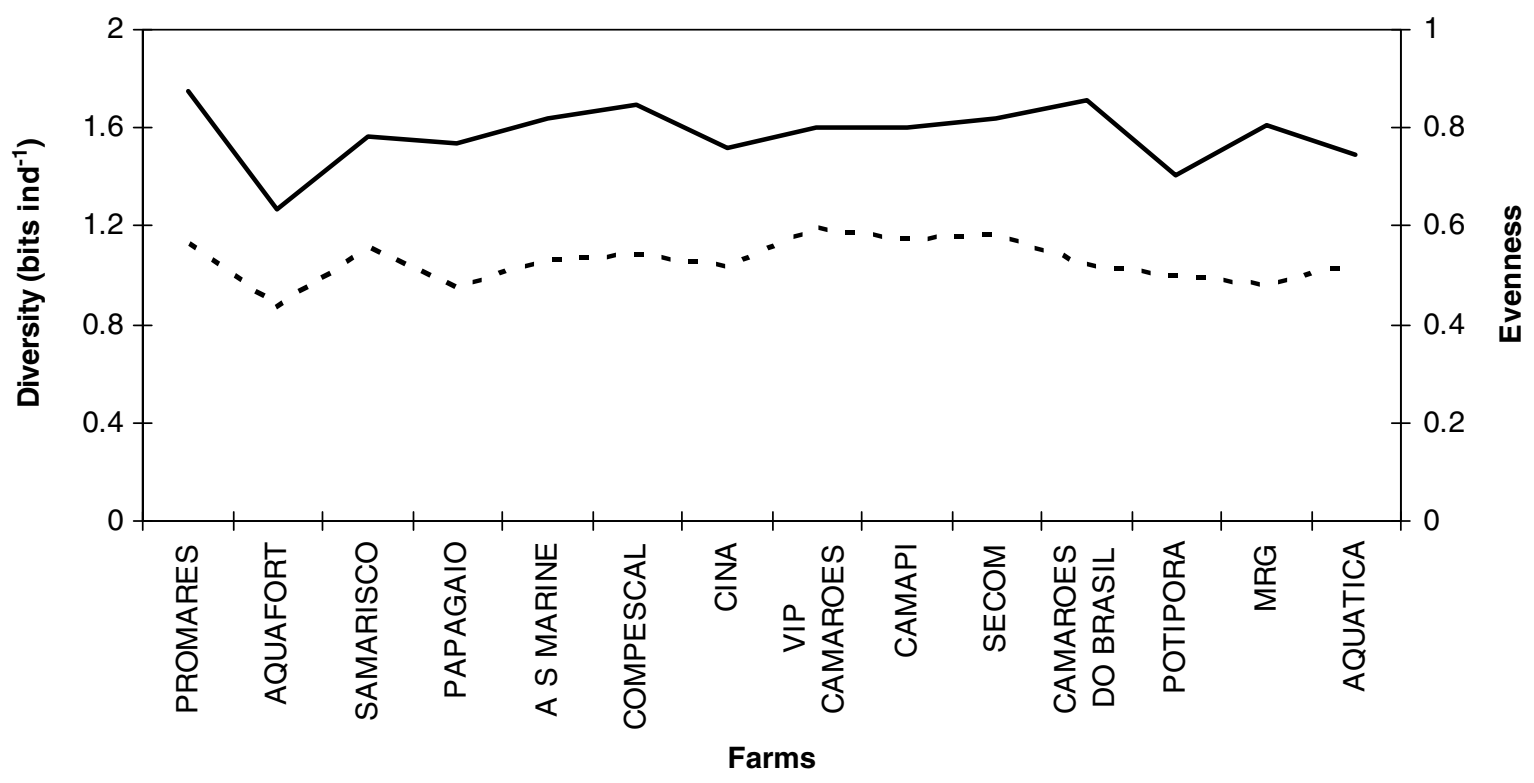

DIVERSITY - - - - EVENNESS

Fig. 4. Species diversity and evenness of the main zooplankton groups in the shrimp farm ponds in Northeastern Brazil. 


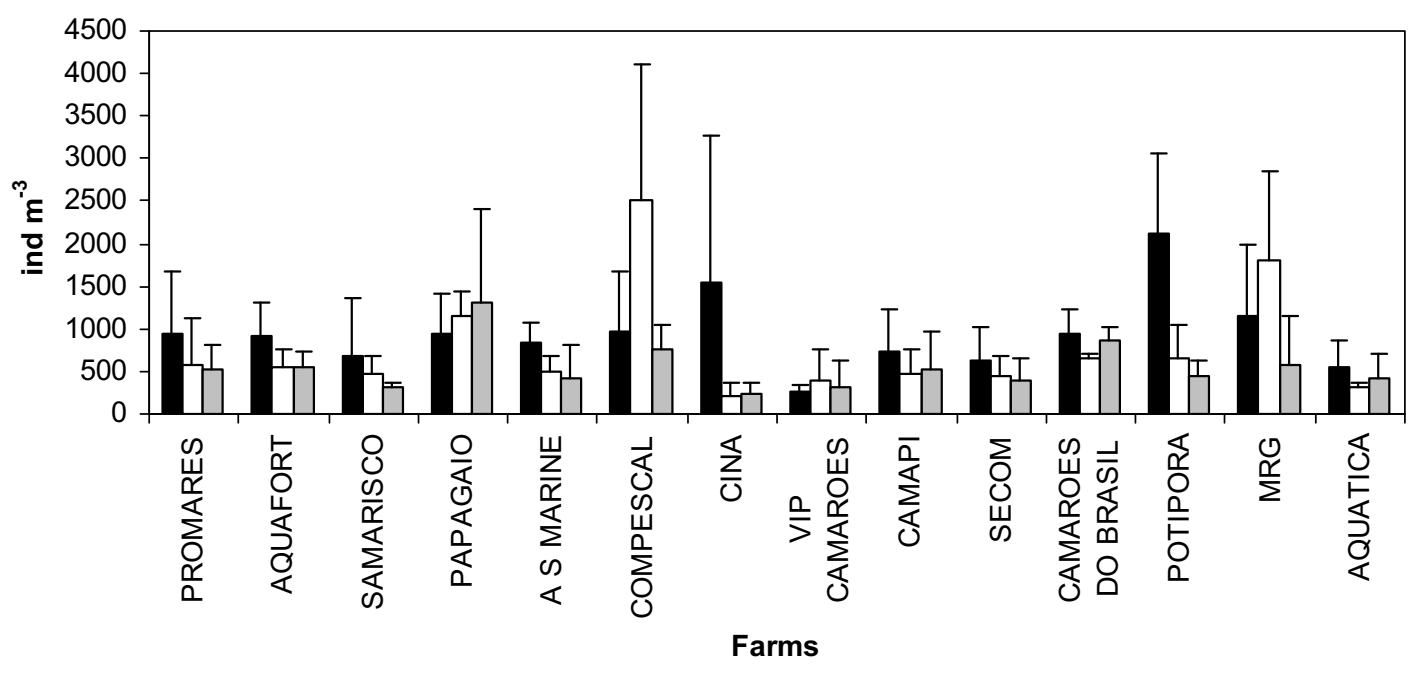

Intake point $\square$ Pond $1 \square$ Pond 2

Fig. 5. Total zooplankton average density and standard deviation in the shrimp farm ponds in Northeastern Brazil.

In general, the intake areas presented better conditions than most ponds, which were often dominated by organic pollution indicators (atecates ciliates, rotifers, polychaeta larvae, nematode, among others). Even presenting strong organic decomposition, there were copepoda nauplii and Bivalve larvae in high densities, showing the great importance of the marine flux in renewing the environment and improvement of environmental health, as it was stated for a highly impacted estuarine area from Northeastern Brazil (Neumann-Leitão and Matsumura-Tundisi, 1998).

It can be concluded that the high amount of atecate ciliates, mainly in the ponds of the Secom and Aquafort farms, indicated a poor water quality. In general, colonization by ciliates occurs concurrently with high levels of organic matter. The dominance of these species in the ponds can favor the bacterioplankton control and add additional food to the ponds. However, in high quantities as presently found in the ponds, indicating an enriched organic matter environment, the effluent of theses ponds can negatively impact the water of the receptor area. In the Cina farm, a Mysis stage with ectoparasites protozoan like Vorticella spp. was registered. These parasites negatively affect the molts and development of the infected organisms, a fact that was observed in this farm and also in the Papagaio farm, where a parasitic nematode was registered.

Studies of zooplankton in shrimp ponds have shown that these are complex assemblages with rapid temporal changes in structure (Coman et al., 2003). The main factors influencing these changes are variations in source of food, predation, and the influences of variations in physical and chemical water quality parameters. The results here suggest that nutrient input provided by shrimp food decomposition affected both the density and the relative species composition of the plankton community. Therefore, plankton assemblages could be an excellent bioindicador of water quality of shrimp ponds. These results can be important in our understanding of the effects of eutrophication in coastal plankton structure and to marine aquatic food web.

\subsection{Statistical analysis}

The factors "station", "campaign", and "farm" on the phyto- and zooplankton data from all farms showed that among the three factors considered, only the factor "station" showed significant differences $(p<0.05)$. These differences were registered between the intake point and the two studied ponds of each farm. Spearman correlation analysis presented similarities between the Promares and Secon farms and among the Aquafort, Cina, Camapi and Potiporã farms. Similar results were found for the differences in key abiotic parameters, (e.g. nutrient concentrations, oxygen demand, and total suspended solids) between intake channels and effluents in shrimp ponds in Texas and Taiwan (Samocha et al., 2004), showing that the alteration of water quality through shrimp farming is a wide-spread problem.

\section{Acknowledgments}

This work was supported by the ABCC (Brazilian Shrimp Farmers Association). We thank the staff from the farms for their valuable help with field work and in collecting the samples. The authors thank Dr. Maria Luise Koening and Dr. Lúcia Maria de Oliveira Gusmão for helpful discussions and for critical reading of the manuscript.

\section{References}

Alongi, D.M., Dixon, P., Johnston, D.J., Tien, D.V., Xuan, T.T., 1999. Pelagic processes in extensive shrimp ponds of the Mekong delta, Vietnam. Aquaculture 175, 121-141. 
Anderson, R.K., Parker, P.L., Lawrence, A., 1987. A ${ }^{13} \mathrm{C} /{ }^{12} \mathrm{C}$ tracer study of the utilization of presented feed by a commercially important shrimp Penaeus vannamei in a pond grow-out system. Journal of the World Aquaculture Society 18, 148-155.

Björnberg, T.S., 1981. Copepoda. In: Boltovskoy, D. (Ed.), Atlas del zooplancton del Atlántico sudoccidental y métodos de trabajo con el zooplancton marino. INIDEP, Mar del Plata, pp. 587-679.

Boyd, C.E., 1990. Water Quality in Ponds for Aquaculture. Auburn University, Alburn AL, USA.

Bratvold, D., Lu, J., Browdy, C.L., 1999. Disinfection, microbial community establishment and shrimp production in a prototype biosecure pond. Journal of the World Aquaculture Society 30, 422432.

Burford, M.A., 1997. Phytoplankton dynamics in shrimp ponds. Aquatic Research 28, 351-360.

Burford, M.A., Costanzo, S.D., Dennison, W.C., Jackson, C.J., Jones, A.B., McKinnon, A.D., Preston, N.P., Trott, L.A., 2003. A synthesis of dominant ecological processes in intensive shrimp ponds and adjacent environments in NE Australia. Marine Pollution Bulletin 46, $1456-1469$.

Capriulo, G.M., Carpenter, E.J., 1983. Abundance, species composition and feeding impact of tintinnid micro-zooplankton in Central Long Island Sound. Marine Ecology Progress Series 10, 277-288.

Capriulo, G.M., Smith, G., Troy, R., Wikfors, G.H., Pellet, J., Yarish, C., 2002. The planktonic food web structure of a temperate zone estuary, and its alteration due to eutrophication. Hydrobiologia 475/476, $263-$ 333.

Coman, F.E., Connolly, R.M., Preston, N.P., 2003. Zooplankton and epibenthic fauna in shrimp ponds: factors influencing assemblages dynamics. Aquaculture Research 34, 359-371.

Costanzo, S.D., O'Donohue, M.J., Dennison, W.C., 2004. Assessing the influence and distribution of shrimp pond effluent in a tidal mangrove creek in north-east Australia. Marine Pollution Bulletin 48, 514-525.

Decamp, O., Conquest, L., Cody, J., Forster, I., 2007. Effect of shrimp stocking density on size-fractionated phytoplankton and ecological groups of ciliated protozoa within zero-water exchange shrimp culture systems. Journal of the World Aquaculture Society 38, 395-406.

D'Ippolito, G., Romano, G., Caruso, T., Spinella, A., Cimino, G., Fontana, A., 2003. Production of octadienal in the marine diatom Skeletonema costatum. Organic Letters 5, 885-887.

Eskinazi-Leça, E., Koening, M.L., Silva-Cunha, M.G.G., 2000. O fitoplâncton: estrutura e produtividade. In: Barros, H.M., EskinaziLeça, E., Macedo, S.J., Lima, T. (Eds.), Gerenciamento participativo de estuários e manguezais. Universitária UFPE, Recife, pp. 67-74, $252 p$.

FAO. 1998. Fishery Statistics: Aquaculture Production, 86/2.

Fenggi, L., 1996. Production and application of rotifers in aquaculture. Aquaculture Magazine 22, 16-22.

Fontana, A., D' Ippolito, G., Cutignano, A., Romano, G., Lamari, N., Gallucci, A.M., Cimino, G., Miralto, A., Ianora, A., 2007. LOXinduced lipid peroxidation mechanism responsible for the detrimental effect of marine diatoms on zooplankton grazers. ChemBioChem 8, $1810-1818$.

Goldman, J.C., Mann, R., 1980. Temperature influenced variations in speciation and chemical composition of marine phytoplankton in outdoor mass culture. Journal of Experimental Marine Biology and Ecology 46, 29-39.

Healy, F.P., 1973. Inorganic nutrient uptake and deficiency in algae. Critical Reviews in Microbiology 3, 6-113.

Horner, R., Rines, J.E.B., Stockner, E. 1991. Chaetoceros convolutus Castracane, Chaetoceros concavicornis Mangin and the mortality of pen-reared salmon in Pacific Northwest waters. In: Smayda, T.J. (Ed.), Fifth Conference on Toxic Marine Phytoplankton, Newport, Abstracts, p. 60.

Islam, S., Sarker, J., Yamamoto, T., Wahab, A., Tanaka, M., 2004. Water and sediment quality, partial mass budget and effluent $\mathrm{N}$ loading in coastal brackishwater shrimp farms in Bangladesh. Marine Pollution Bulletin 48, 471-485.
Jones, A.B., Jones, M.J., O'Donohue, J., Denninson, W.C., 2001. Assessing ecological impacts of shrimp and sewage effluent: biological indicators with Standard water quality analysis. Estuarine, Coastal and Shelf Science 52, 91-109.

Lacerda, L.D., Vaisman, A.G., Maia, L.P., Silva, C.A.R., Cunha, E.M.S., 2006. Relative importance of nitrogen and phosphorus emissions from shrimp farming and other anthropogenic sources for six estuaries along the NE Brazilian coast. Aquaculture 253, 433-446.

Landesman, L., 1994. Negative impacts of coastal aquaculture development. World Aquaculture 25, 12-17.

Lubzens, L., 1987. Raising rotifers for use in aquaculture. Hydrobiologia 147, 245-255.

Martinez-Cordova, L.R., Porchas-Cornejo, M.A., Villarreal-Colmenares, H., Calderon-Perez, J.A., 1998. Effect of aeration on chlorophyll a, zooplankton, and benthos in yellowleg shrimp, Penaeus californiensis ponds. Journal of Applied Aquaculture 8, 17-23.

Naylor, R.L., Goldburg, R.J., Mooney, H., Beveridge, M., Clay, J., Folke, C., Kautsky, N., Lubchenco, J., Primavera, J., Williams, M., 1998. Nature's subsidies to shrimp and salmon farming. Science 282, 883-884.

Neumann-Leitão, S., Gusmão, L.M.O., Silva, T.A., Nascimento-Vieira, D.A., Silva, A.P., 1999. Mesozooplankton biomass and diversity in coastal and oceanic waters off North-Eastern Brazil. Archives of Fisheries and Marine Research 47, 153-165.

Neumann-Leitão, S., Matsumura-Tundisi, T., 1998. Dynamics of a perturbed Estuarine Zooplanktonic Community: Port of Suape, PE, Brazil. Verhandlungen Internationale Vereinigung Limnologie 26, 1981-1988.

Neumann-Leitão, S., Paranaguá, M.N., Valentin, J.L., 1992. Ecology of Planktonic Rotifera of the Estuarine Lagunar Complex at Suape, Pernambuco (Brazil). Hydrobiologia 232, 133-143.

Paerl, H.W., 1988. Nuisance phytoplankton blooms in coastal, estuarine and inland waters. Limnology and Oceanography 33, 823-847.

Paerl, H.W., 1997. Coastal eutrophication and harmful algal blooms: importance of atmospheric deposition and groundwater as "new" nitrogen and other nutrient sources. Limnology and Oceanography 42, 1154-1165.

Paerl, H.W., Tucker, C.S., 1995. Ecology of blue-green algae in aquaculture ponds. Journal of the World Aquaculture Society 26, 109-131.

Paez-Osuna, F., Guerrero-Galván, S.R., Ruiz-Fernández, A.C., 1998. The environmental impact of shrimp aquaculture and the coastal pollution in Mexico. Marine Pollution Bulletin 36, 65-75.

Paez-Osuna, F., Guerrero-Galván, S.R., Ruiz-Fernández, A.C., 1999. Discharge of nutrients from shrimp farming to coastal waters of the Gulf of California. Marine Pollution Bulletin 38, 585-592.

Pielou, E.C., 1967. An Introduction to Mathematical Ecology. WileyIntercience, NY, p. 286.

Pierce, R.W., Turner, J.T., 1993. Global biogeography of marine tintinnids. Marine Ecology Progress Series 94, 11-26.

Preston, N.P., Coman, F.E., Fry, V.M., 2003. Shrimp pond zooplankton dynamics and the efficiency of sampling effort. Aquaculture Research 34, 373-381.

Primavera, J.H., 1998. Tropical shrimp farming and its sustainability. In: Silva, S.S. (Ed.), Tropical Maricuture. Academic Press, London, pp. 257-289.

Raymont, J.E.G., 1980. Plankton and productivity in the oceans. In: Phytoplankton, vol. 1. Pergamon Press, Oxford.

Rey, L. 2002. Bases da Parasitologia Médica. 2a. Ed., Rio de Janeiro: Guanabara Koogan.

Rocha, I.P., Rodrigues, J., Amorim, L., 2004. A carcinocultura Brasileira em 2003. Revista ABCC 6, 1-8.

Rodriguez, R.A., Paez-Osuna, F., 2003. Nutrients, phytoplankton and harmful algal blooms in shrimp ponds: a review with special reference to the situation in the Gulf of California. Aquaculture 219, 317-336.

Romano, G., Russo, G.L., Buttino, I., Ianoro, A., Miralto, A., 2003. A marine diatom-derived aldehyde induces apoptosis in copepoda and sea urchim embryos. The Journal of Experimental Biology 206, 3487-3494.

Rubright, J.S., Harrel, J.L., Parker, J.C., 1981. Responses of planktonic and benthic communities to fertilizers and feed applications in shrimp 
mariculture ponds. Journal of the World Aquaculture Society 121, 281-299.

Ryther, J.H., Officer, C.B., 1981. Impact of nutrient enrichment on water uses. In: Neilson, B.J., Cronin, L.E. (Eds.), Estuaries and Nutrients. Humana Press Inc., Totawa NJ, USA, pp. 247-262.

Saksena, N.D., 1987. Rotifera as indicators of water quality. Hydrobiologia $15,481-485$.

Samocha, T.M., Lawrence, A.L. 1995. Shrimp farms effluent waters, environmental impact and potential treatment methods. In: Proceedings of 24th US-Japan Aquaculture Panel Symposium, Corpus Christi, Texas, October 8-10, 1995.

Samocha, T.M., Lopez, I.M., Jones, E.R., Jackson, S., Lawrence, A.L., 2004. Characterization of intake and effluent waters from intensive and semi-intensive shrimp farms in Texas. Aquaculture Research 35, $321-$ 339.

Sampaio, Y., Costa, E.F., Albuquerque, E., Sampaio, B.R., 2005. Impactos sócio-econômico do cultivo do camarão marinho em municípios selecionados do Nordeste brasileiro. Revista ABCC 7 (3), $1-13$.

Sanders, J.G., Cibik, S.J., D'Ella, C.F., Boynth, W.R., 1987. Nutrient enrichment studies in a coastal plain estuary: changes in phytoplankton species composition. Canadian Journal of Fisheries and Aquatic Science 44, 83-90.

Scheffer, M., Rinaldi, S., Gragnani, A., Mur, L.R., Van Nes, E.H., 1997. On the dominance of filamentous cyanobacteria in shallow, turbid lakes. Ecology 78 (1), 272-282.

Shannon, C.E., 1948. A mathematical theory of communication. Bell System Technical Journal 27, 379-423, 623-656.

Smith, D.W., 1985. Biological control of excessive phytoplankton growth and the enhancement of aquaculture production. Canadian Journal of Fisheries and Aquatic Science 42, 1940-1945.
Smith, V.H., 1983. Low nitrogen to phosphorus ratio favors dominance by blue-green algae in lake phytoplankton. Science 211, 669-671.

Snell, T.W., Carrillo, K., 1984. Body size variation among strains of the rotifer Brachionus plicatilis. Aquaculture 37, 359-367.

Tillmann, U., 2004. Interactions between planktonic microalgae and protozoan grazers. The Journal of Eukaryotic Microbiology 51, 156168.

Tookwinas, S., Songsangjinda, P., 1999. Water quality and phytoplankton communities in intensive shrimp culture ponds in Kung Krabaen Bay, eastern Thailand. Journal of the World Aquaculture Society 30, 3645.

Tundisi, J.G., 1970. O plâncton estuarino. Contribuições avulsas do Instituto Oceanográfico de São Paulo, série Oceanografia Biológica 19, pp. 1-22.

Urrutxurtu, I., 2004. Seasonal succession of tintinnids in the Nervión river estuary, Basque Country, Spain. Journal of Plankton Research 26, 307-314.

Webber, D.F., Webber, M.K., 1998. The water quality of Kingston Harbor: evaluating the use of the planktonic community and traditional water quality indices. Chemistry and Ecology 14, 357-374.

Yusoff, F.M., McNabb, C.D., 1997. The effects of phosphorus and nitrogen addition on phytoplankton dominance in tropical ponds. Aquaculture Research 28, 591-597.

Yusoff, F.M., Zubaidah, M.S., Matias, H.B., Kwan, T.S., 2002. Phytoplankton succession in intensive marine shrimp culture ponds treated with a commercial bacterial product. Aquaculture Research 33, 269 278.

Zar, J.H., 1990. Biostatistical analysis, 2a. Prentice Hall, NJ, p. 718. 